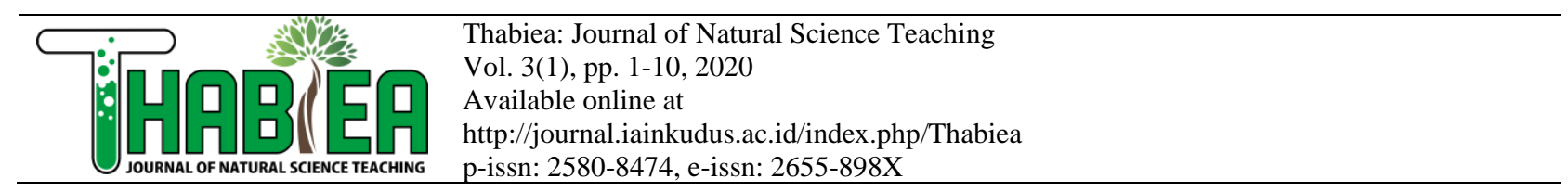

\title{
Analysis of Learning Activity Facilitating Argumentation Skill on Cloning Topic in Islamic Senior High Schools by Using Video
}

\author{
Afridha Laily Alindra ${ }^{1,2 *}$, Ari Widodo ${ }^{3}$, Taufik Rahman ${ }^{3}$, Riandi $^{3}$ \\ ${ }^{1}$ Program of Science Education, Postgraduate School of Indonesian Education University, \\ Jl. Dr. Setiabudi No. 229, Bandung 40154, Indonesia \\ ${ }^{2}$ SMA Negeri 1 Sijunjung West Sumatera, Indonesia \\ ${ }^{3}$ Department of Biology Education, Indonesian Education University, \\ Jl. Dr. Setiabudi No. 229, Bandung 40154, Indonesia
}

*Correspondence: lailyalindra@gmail.com

\begin{tabular}{ll}
\hline Key word: & Abstract \\
Argumentation & Students will achieve the expected science education outcomes by giving more \\
Cloning & chances for scientific argumentation through building an argument, considering it, and \\
Learning Video & and fast process, therefore the use of video can be a solution since the learning process \\
can be explained in detail and observed repeatedly so that it can be analyzed properly. & This study aims to analyze learning activities that facilitate the argumentation in \\
biology on the topic of cloning in high schools. The study was conducted in three \\
Islamic-based Private High Schools in South Tangerang City, Banten Province, \\
Indonesia. The descriptive analysis method for Biology learning activities is recorded \\
in full by using a video camera, then the video is transcribed and analyzed to \\
determine the continuity of argumentation skills. The results of the analysis show that \\
there is still a lack of scientific argumentation skills in learning cloning topic. Learning \\
experiences taken by students have not provided an opportunity for in-depth scientific \\
argumentation. It is necessary for biology learning efforts which can improve students' \\
science argumentation skills.
\end{tabular}

To cite this article:

Alindra, A.L., Widodo, A., Rahman, T., Riandi. (2020). Analysis of Learning Activity Facilitating Argumentation Skill on Cloning Topic in Islamic Senior High Schools by Using Video. Thabiea: Journal of Natural Science Teaching, 3(1), 1-10.

\section{Introduction}

Argumentation is a necessary skill to be given to students, since (1) a studied explanation, model and theory of a concept can be built through argumentation skill (Zohar \& Nemet, 2002), training cognitive and affective skills in understanding basic science concepts and processes can be built by training argumentation skill (Sampson \& Gerbino, 2010; Erduran, \& Maria, 2008), (2) Ideally, provision of cognitive skill must be completed by the provision of argumentation skills in science learning (Osborne, et al., 2004; Cross, et al., 2008; Kuhn, 2010).

Regulation of Minister of Education and Culture number 54 of 2013 concerning Graduate Competency Standard obliges students to have thinking skills. In this study, the referred thinking skill is argumentation skill. Initial findings are based on findings by Sondang (2012) and Muslim (2012), which find out that most students have fewer skills in writing science argumentation. They create argumentation by providing fewer proofs and 
supports which can ensure the validity of the proposed claims. One effort to improve argumentation skills is to use the argument generator learning model. The argument generation learning models can be designed to train students' argumentation skills including skills in making claims, data, justification, support, and reputation based on the problems given (Sampson, \& Gerbino, 2010). It is necessary to take observations on the teaching and learning process in biology class to observe the continuity of learning argument generation.

In general, there are two main strategies to observe the teaching and learning process in the classroom, namely by direct observation and indirect observation by the assistance of audio and video camera records (Widodo, 2005).

Indirect observation using video recording has several advantages compared to direct observation. First, video can be played back, slowed, and several other possibilities; video observation allows researchers to observe teaching and learning processes better even though the process is complex and takes place quickly (Stigler et al., 1999). Second, video recordings can be reproduced and moved easily, learning activities in one place can be analyzed by several people in several places. This also allows for experience exchange without having to be present directly at the location. Third, learning video records allow for unlimited analysis from various aspects by observers without having to interfere with ongoing learning activities. Thus, learning activities can be described as more comprehensively without any constraints of space and time from the observers.

Based on the above background, this study aims to analyze learning activities that facilitate the argumentation in biology on the topic of cloning in the Islamic high schools by using video.

\section{Method}

This research is a descriptive analysis of cloning biology learning activities through learning video recording and interviews. The subjects of this study were teachers and students from three Islamic organization-based high schools in South Tangerang City, Banten Province. In this study, there were three biology teachers from three schools with different backgrounds of Islamic organizations, namely Nahdlatul 'Ulama (NU), Muhammadiyah, and the Integrated Islamic School Network (JSIT). The private Islamic schools also differ ideologically. This is reflected in the presence of three streams in private Islamic education, which are coordinated and run by three large non-governmental Muslim organizations that play an important role in the delivery of educational services: a modernist stream (Muhammadiyah), a traditionalist stream (NU), and an integrationist stream (JSIT) (Muttaqin, Wittek, Heyse, \& van Duijn, 2019). In order to keep the subject's identity anonymous, then the three schools were randomly coded as schools A, B, and C. Recording learning activities by the teacher for one face-to-face in the duration of the two lesson hours was done with one or more cameras. The camera captures the interaction between the teacher and students, students, and students in the classroom setting. Thus, in addition to these activities, such as interactions between students in a group or between groups outside the classroom setting are not seen as the focus of observation. The recording is done without editing and taken as a whole (Widodo, 2006). The videos were analyzed from two aspects, namely: the discussed materials in learning, and the teaching and learning process that revealed argumentation skills and their duration. After the recording process takes place, then the video is copied to the 
laptop in digital form. The first process for the analysis preparation is to transcribe learning videos containing conversations between the teacher and students which are then transcribed all as they are spoken by them. From the transcription results, then the video is analyzed according to the researcher's focus. In this study, data analysis was done descriptively after paying attention to the studied aspects and their appearance in recorded learning.

\section{Results and Discussion}

\section{The discussed materials in the learning}

The discussed topic during the learning activities is about "cloning". The discussed cloning material refers to the basic competencies required by the curriculum, namely KD. 3.10; namely analyzing the principles of Biotechnology and its application as an effort to improve human welfare. In Table 1, the structure of the discussed concepts is presented, as well as its duration of time and the methods.

Table 1. Concept structure, duration, and method of cloning topic learning in three schools

\begin{tabular}{llll}
\hline $\begin{array}{l}\text { School } \\
\text { code }\end{array}$ & Concepts & $\begin{array}{c}\text { Duration } \\
\text { (minutes) }\end{array}$ & Methods \\
\hline A & Definition of cloning & $2: 59$ & Lecturing \\
\cline { 2 - 4 } & Types and impacts of cloning & $45: 10$ & Group discussion and class discussion \\
\cline { 2 - 4 } & Islamic perception of cloning & $2: 00$ & Class discussion \\
\cline { 2 - 4 } & Total & $\mathbf{5 0 : 0 9}$ & \\
\hline B & $\begin{array}{l}\text { Definition of cloning, types, and } \\
\text { history of cloning }\end{array}$ & $24: 00$ & Lecturing \\
\cline { 2 - 4 } & Prohibition for human cloning & $2: 00$ & Lecturing \\
\cline { 2 - 4 } & Benefits and impacts of cloning & $6: 00$ & Lecturing \\
\cline { 2 - 4 } & $\begin{array}{l}\text { Examples of animal and human } \\
\text { cloning }\end{array}$ & $18: 00$ & Watching video \\
\cline { 2 - 4 } & Total & $\mathbf{5 0 : 0 0}$ & \\
\hline C & $\begin{array}{l}\text { Definition of cloning, types, and } \\
\text { history of cloning }\end{array}$ & $18: 18$ & Lecturing \\
\cline { 2 - 4 } & Some arguments on cloning & $13: 51$ & Lecturing and watching video \\
\cline { 2 - 4 } & Pro contra of cloning & $34: 00$ & Group discussion and class discussion \\
\cline { 2 - 3 } & Total & $\mathbf{6 6 : 0 9}$ & \\
\hline
\end{tabular}

The table above also shows that learning activities generally discuss several main concepts, namely understanding, types of cloning, impacts, and argumentations on cloning. In the discussion about cloning, there are several different aspects in each school as the discussion focus, namely in terms of the types of cloning, the ways and views of the pros and cons of cloning.

At school A, the longest (duration) discussion was the longest in three types of cloning namely; cloning in animals, plants and humans, which is done through a group discussion method for 20 (twenty) minutes, after the teacher distributes the worksheets and continues with group presentations within 15 minutes: 10 seconds. These types of cloning discuss starting from the principle of cloning in animals, plants, humans, examples, and their impacts, both positive and negative impacts. The arising questions from students for the presenting group on the cloning in animals are about the mechanism of cloning in cats that China has done, as well as differences in cloning in animals with normal animal reproduction. The question about cloning in plants is about the discoverer and what year tissue culture was 
discovered, and the law of tissue culture in Islam. The question about cloning in humans is the difference between cloning and IVF and whether the results of cloning from humans will be the same as the original human. In general, the questions given by these students are still at the cognitive level of remembering (C1) and understanding (C2). This can be caused because students still have a low level of knowledge about cloning, so students' reasoning and critical thinking have not yet been fully seen. Examples of student questions related to cloning in humans are recorded in the following transcript:

Student 1: yes, I am from the 3rd group, I want to ask, what is the difference between human cloning and in-vitro fertilization (IVF)?

Student 2: ok we will answer the question from some groups, the 3rd group? ok, I will explain what is the difference between human cloning and IVF, if human cloning comes from human cells and ovum human cells, whereas if IVF is from ovum cells from sperm cells, yes, so it is like fertilization in tubes, if cloning, it doesn't have sperm cells, so it's different. Thanks.

At school B, the longest duration in the discussion is for discussion on types of cloning namely embryo splitting, recombinant DNA technology, and the SCNT (somatic cell nuclear transfer) process through lecturing and examples of successfully cloned animals and humans through YouTube shows. In this study, students only submit two questions to the teacher, namely whether identical twins and cloning are the same and the origin donor cells of animal cells? These questions are also in the level of remembering (C1) and understanding (C2). Examples of student questions related to cloning in animals are recorded in the following transcript:

Student: Sir, for identical twins, can we say it as a result of cloning?

Teacher: oooh about identical twin, we can call it as natural cloning, it is not the artificial one, naturally from the uterus, it has been cloned from there naturally, but it splits repeatedly from one egg, right, if identical twins come from one egg that is fertilized by several sperm cells, yes, it can be two or more, then divide, if it splits perfectly it can so identical twins, if the splitting is not perfect, it can be conjoined twins, right, It sticks. Each cell splits repeatedly into new individuals, each cell is called a natural cloning process, not deliberate cloning. made intentionally but naturally.

At school $\mathrm{C}$, the longest duration is in the discussion of the pros and cons of human cloning from the student perspective. Students are divided into two large groups namely pros and cons. Each group gave their arguments against the statement they made. In this section, students express arguments based on their logic, social views, religion, and culture, while it could not be seen any scientific arguments. Examples of student questions related to cloning in humans are recorded in the following transcript:

Student 1(pro): good afternoon my friends, we are from the world union clone advocates, would like to argue that biotechnology cannot be separated from human life, as we know, we support cloning or multiplication not because we want to rival God, but want to reduce any sad people because they do not have kids, people who have lost their organs or people who have incurable diseases, we are sure that in the future we will develop this. 
Student 2 (cons): we respect biotechnology as technological development today, but we disagree because the first clone is not following essence and nature, the second, it is not in accordance with religion, although it can help couples who do not have children, third, in terms of ethics and morals, in terms of morals, it lacks respect the right of every human being from a legal partner to fertilize a child even though there is a lack of technology-assisted, at least if one cannot fertilize a child, there are other solutions to have children. What's the solution? as the solution, we can raise a child from an orphanage, if it really can't be fertilization for a child, we don't have to clone from other people's cells, right.

From the data above, it can be interpreted that it is still necessary for an improvement in building students' argumentation skills scientifically on the topic of cloning still. Improving students' skills to build arguments about controversial science topics is the desired outcome of science education. The purpose of such an argument is to explain some of the scientific or social phenomena (Nussbaum, Sinatra, \& Owens, 2012). The purpose of science education is not to train students as specialists in certain domains of knowledge, but to encourage them to engage in general discourse and argumentation specifically in terms of social constructivist understanding. Thus, students must be given the opportunity to articulate their position in the classroom atmosphere which must be designed from a social constructivist perspective and their argumentation must be consistent with constructivist epistemology. In turn, any presenting dialogue in science lessons can be considered as a particular type of discourse that combines student culture, which is based on a large portion of everyday knowledge, and science in schools (Aguiar, 2016; Bricker \& Bell, 2008; Erduran \& Jimenez- Aleixandre, 2007).

In terms of duration for the delivery of the cloning content above, it can be seen that learning has provided a considerable portion for extracting the cloning content, both from the process of providing information directly from the teacher through lectures and video observations such as at school B and through information searching through the internet and any sourcebooks by students such as at schools A and C. Understanding of science concepts is very necessary for the process of arguing science. But in this study, such a method could apparently not be able to improve students' argumentation skills.

The students' scientific reasoning towards cloning is still low indicated by the statements raised in class discussions that are still at the cognitive level of remembering (C1) and understanding (C2). Student science reasoning is closely related to students' argumentative abilities. The results of the study (Zohar \& Nemet, 2002) show that students' reasoning about science can be improved by applying arguments in learning.

Modern biotechnology has served as one of the most important scientific and technological revolutions of the twenty-first century (Kirkpatrick, Orvis, \& Pittendrigh, 2002). Therefore, products from modern biotechnology processes such as genetic engineering, DNA testing, and cloning will increasingly have an impact on society (Lappan, 2000) and will cause controversy. Students should have a well-developed scientific understanding of these processes so they can contribute to public debate and make scientific personal decisions (Dawson, 2007). 


\section{Do the students relate to their faith?}

From one of the schools, in their class discussion, students revealed the basis of Islam in dealing with cloning. His statement is recorded in the following transcript:

Student 1: cloning in Islam, human cloning technology has negative implications both on the institution of marriage, nasab, guardianship, inheritance, and can underestimate marriage, because of that Islamic law in Indonesia prohibits human cloning, the clause that alludes to cloning is Qur'an surah Al-Hajj verse 5: We indeed created you from dust, then from a drop of [seminal] fluid, then from a clinging mass, 1 than from a fleshy tissue,2 partly formed and partly unformed, so that We may manifest [Our power] to you. We establish in the wombs whatever We wish for a specified term".

Student 2: I would add that if the child is cloned unnaturally, there is a Qur'anic verse that touches on it, the Quran An-Najm verses 45-46, which means "and that it was He who created male and female pairs from the emitted semen. "then the child is cloned from women alone without a man, so the cloned child does not have a father because it is produced from women with women, then the verse reads "call them adopted children by the name of their fathers" it is the Qur'an surah Al Ahzab verse 5.

There are many topics including in science education which are recognized as controversial issues, for example, cloning, abortion, and genetic engineering. These problems pose problems for science teachers, especially in faith-based cultures, because of the nature of the conflict between the implications of scientific studies of some of these problems and religion (Mansour, 2008). Therefore, genetic literacy is becoming increasingly important due to advances in the application of genetic technology such as cloning that has been done in more places.

Cloning is one of the topics in socio-scientific issues. The general way to develop students' scientific argumentation skills is through argumentation on socio-scientific issues, which are defined as scientific problems with social, ethical, and moral aspects (Belland, $\mathrm{Gu}$, Armbrust, \& Cook, 2015). The ability to negotiate and solve problems related to sociocultural issues has been proposed as an integral component of scientific literacy. Although philosophers and educators of science argue that sociological problems inherently involve moral and ethical considerations, the problem of morality is the determinant of individual decision making (Sadler \& Zeidler, 2004). Socio-scientific issues are concept-based issues and scientific problems, any arising controversies, and public discussions that are influenced by social politics (Sadler \& Zeidler in Dawson \& Venville, 2009). More students are involved in thinking critically and solving problems on socio-cultural issues will lead to increased science literacy. Since scientific literacy is the ability to use scientific processes and principles in personal decision making and participate in discussions about science issues that affect the social environment and make decisions on those issues. Discussion of socio-cultural issues related to morals and ethics leads to more students' interests in science. Science is becoming more relevant to everyday life.

The concept of cloning is one of the concepts that raise the pros and cons of the religious, socio-cultural side. Judging from official documents relating to the moral and legal aspects of cloning of human reproduction, there seems to be a consensus around the world 
that reproductive cloning is incompatible with human dignity. The research concluded that the main objection to cloning of human reproduction is not an objection related to dignity but an objection related to risk, especially the risk imposed on children born in the process of testing the safety of this method (Birnbacher, 2005).

\section{Learning stages encouraging argumentations}

One of the demands in the 2013 curriculum is to use a scientific approach in learning. Using this approach can leverage students' argumentation skills. Science learning that involves scientific argumentation does not occur naturally but must be planned carefully. The focus and learning model must be adjusted and the teacher must be able to direct students how to build and support knowledge through arguments and assessing and responding to statements or arguments submitted by others (Probosari, et al, 2016). From research by Siswanto, Kaniawati, and Suhandi (2014), it stated the relationship between the use of a scientific approach and Argument Generating Learning and the expected level of cognitive or competence which is illustrated in Table 2.

Table 2. Matrix of relationships between stages of the argument generation learning model using scientific methods with expected competencies.

\begin{tabular}{|c|c|c|}
\hline \multicolumn{2}{|r|}{ Learning stages } & Expected cognitive ability \\
\hline \multicolumn{3}{|c|}{ INTRODUCTION } \\
\hline \multicolumn{2}{|c|}{$\begin{array}{l}\text { (1) Giving apperception; (2) Exploring initial concepts; (3) Providing } \\
\text { motivation }\end{array}$} & $\begin{array}{l}\text { Remembering }(\mathrm{C} 1) \\
\text { Remembering }(\mathrm{C} 1)\end{array}$ \\
\hline \multicolumn{3}{|c|}{$\begin{array}{ll} & \text { INITIAL ACTIVITIES } \\
\end{array}$} \\
\hline \multirow[t]{5}{*}{ Stage I } & $\begin{array}{l}\text { Planting Concepts, Identifying problems, questions and } \\
\text { assignments using scientific methods }\end{array}$ & Understanding (C2) \\
\hline & $\begin{array}{l}\text { Observing: Providing opportunities for students to make } \\
\text { observations of the demonstrations }\end{array}$ & Understanding $(\mathrm{C} 2)$ \\
\hline & $\begin{array}{l}\text { Asking: Providing opportunities for students to ask } \\
\text { questions based on their observations of the } \\
\text { demonstrations }\end{array}$ & Understanding $(\mathrm{C} 2$ \\
\hline & $\begin{array}{l}\text { Reasoning: Providing opportunities for students to discuss } \\
\text { answering any arising questions and searching for } \\
\text { information in textbooks }\end{array}$ & Understanding (C2) \\
\hline & $\begin{array}{l}\text { Try: Conducting an experiment based on the problem } \\
\text { presented; Gathering experimental data to answer the } \\
\text { problem; Analyzing data on experimental results; } \\
\text { Working on student worksheets }\end{array}$ & $\begin{array}{l}\text { Understanding } \quad(\mathrm{C} 2), \\
\text { Applying (C3), Analyzing } \\
(\mathrm{C} 4)\end{array}$ \\
\hline \multirow[t]{2}{*}{ Stage II } & $\begin{array}{l}\text { Making tentative arguments (Students make provisional } \\
\text { arguments based on the results of experiments to be }\end{array}$ & $\begin{array}{l}\text { Understanding (C2), Applying } \\
\text { (C3), Analyzing (C4), Making }\end{array}$ \\
\hline & $\begin{array}{l}\text { discussed in front of the class); Making tentative } \\
\text { arguments; Group discussion makes tentative arguments }\end{array}$ & $\begin{array}{l}\text { Claims, Data, Warrant, } \\
\text { Backing, Rebuttal }\end{array}$ \\
\hline $\begin{array}{l}\text { Stage } \\
\text { III }\end{array}$ & $\begin{array}{l}\text { Presenting Arguments; Presentation related arguments } \\
\text { that have been made; Discussing between groups about } \\
\text { the results of the arguments }\end{array}$ & $\begin{array}{lr}\text { Understanding } & (\mathrm{C} 2), \\
\text { Analyzing (C4), Submitting } \\
\text { Claims, Data, } \\
\text { Backing, Rebuttal }\end{array}$ \\
\hline $\begin{array}{l}\text { Stage } \\
\text { IV }\end{array}$ & $\begin{array}{l}\text { Correcting Arguments; Evaluating the arguments that } \\
\text { have been discussed between groups; Making final } \\
\text { argument on the discussion results between groups }\end{array}$ & $\begin{array}{l}\text { Submitting Claims, Data, } \\
\text { Warrant, Backing, Rebuttal }\end{array}$ \\
\hline
\end{tabular}

\section{CLOSING}

(1) Making corrections and strengthening materials; (2) Summing up the material being studied

Remembering (C1),

Understanding (C2) 
The development of learning techniques as an effort to improve reasoning and argumentation skills among students is to provide guidance and direction to the discussion process, especially on improving students' reasoning collaboratively (Macagno, MaywegPope \& Kuhn, 2015). Furthermore, Sampson (2010) revealed that the argument generation learning model can equip students to: (1) make it easier to construct arguments to explain the problem, (2) develop the ability to make claims, (3) develop the ability to include evidence or data to support claims, (4) develop the ability to analyze and explain evidence to support claims; and (5) develop the ability to write scientific arguments.

\section{Conclusion}

From the video analysis of cloning topic learning in the three schools, it appears that the implementation of learning that facilitates students' argumentation skills is still lacking. In general, the arguments presented by students are limited to the ability to submit claims and some to the delivery of data and warrant. This is closely related to students' scientific reasoning. In learning, the discussion that occurs is still around the cognitive level of remembering and understanding. Whereas the topic of cloning is a controversial issue that can be viewed in terms of social, religious, and cultural aspects. Therefore it is necessary to build a learning model that can leverage students' scientific argumentation skills on the topic of cloning.

\section{Acknowledgment}

The author would like to express his gratitude and highest appreciation to the LPDP Ministry of Finance of the Republic of Indonesia for the dissertation scholarship given, Mr. Dr. Supandi, supervisor of the Education Office, Banten Province for his permission in facilitating this research, as well as teachers who are willing to be involved in this activity. It certainly appreciates their courage since they are willing to be observed and become study material for researchers.

\section{References}

Aguiar, O. G. (2016). Explanation, argumentation, and dialogic interactions in science classrooms. Cultural Studies of Science Education, 11(4), 869-878.

Belland, B. R., Gu, J., Armbrust, S., \& Cook, B. (2015). Scaffolding argumentation about water quality: a mixed-method study in a rural middle school. Educational Technology Research and Development, 63(3), 325-353. https://doi.org/10.1007/s11423-0159373-x

Birnbacher, D. (2005). Human cloning and human dignity. Reproductive BioMedicine Online, 10(SUPPL. 1), 50-55. https://doi.org/10.1016/S1472-6483(10)62206-7

Bricker, L. A., \& Bell, P. (2008). Conceptualizations of argumentation from science studies and the learning sciences and their implications for the practices of science education. Science Education, 92(3), 473-498. https://doi.org/10.1002/sce.20278

Cross, D., Taasoobshirazi, G., Hendricks, S., \& Hickey, D. (2008). Argumentation: A Strategy for Improving Achievement and Revealing Scientific Identities. International Journal of Science Education, 30 (6), 837-861.

Dawson, V. (2007). An Exploration of High School (12-17-Year-Old) Students' Understanding of, and Attitudes Towards Biotechnology Processes. Research in Science Education, 37, 59-73 
Erduran, S., \& Jimenez-Aleixandre, M. P. J. (2007). Argumentation in Science Education Perspectives from Classroom-Based Research. (S. Erduran \& M. P. J. Aleixandre, Eds.). Netherlands: Springer Netherlands.

Erduran, S., \& Maria, P. (2008). Argumentation in Science Education. London: Springer Science.

Kirkpatrick, G., Orvis, K. S., \& Pittendrigh, B. (2002). Genomic Analogy Model for Educators (GAME): A teaching model for biotechnology and genomics education. Journal of Biological Education, 37(1), 31-35.

Kuhn. (2010). Teaching and Learning Science as Argument. Wiley Periodicals, Inc. Sci Ed, v (94) ,810-824

Lappan, G. (2000). A vision of learning to teach for the 21st century. School Science and Mathematics, 100, 319-325.

Macagno, F., Mayweg-Paus, E., \& Kuhn, D. (2015). Argumentation Theory in Education Studies: Coding and Improving Students' Argumentative Strategies. Topoi 34, 523537.

Mansour, N. (2008). Religious beliefs: A hidden variable in the performance of science teachers in the classroom. European Educational Research Journal, 7(4), 557-576. https://doi.org/10.2304/eerj.2008.7.4.557

Muslim, \& Suhandi, A. (2012). Development of School Physics Learning Tools to Improve Cognitive Ability and Argumentation Skills. Indonesian Journal of Physical Education, 8, 174-183

Muttaqin, T., Wittek, R., Heyse, L., \& van Duijn, M. (2019). The achievement gap in Indonesia? Organizational and ideological differences between private Islamic schools. School Effectiveness and School Improvement, O(0), 1-31. https://doi.org/10.1080/09243453.2019.1644352

Nussbaum, E. M., Sinatra, G. M., \& Owens, M. C. (2012). Perspectives on Scientific Argumentation. (M. S. Khine, Ed.). Dordrecht: Springer. https://doi.org/10.1007/97894-007-2470-9

Osborne, J., Erduran, S., \& Simon, S. (2004). Enhancing he Quality of Argumentation in School Science. Journal of Research in Science Teaching, 41(10), 994-1020.

Probosari, R.M, Ramli, M., Harlita, Indrowati, M., \& Sajidan. (2016). Profile of Scientific Argumentation Skills Profiles of FKIP UNS Biology Education Students in Plant Anatomy Subjects. Bioeducation: Journal of Biological Education. 9(1), 29-33.

Sadler, T. D., \& Zeidler, D. L. (2004). The Morality of Socioscientific Issues: Construal and Resolution of Genetic Engineering Dilemmas. Science Education, 88(1), 4-27. https://doi.org/10.1002/sce.10101

Sampson, V., \& Gerbino, F. (2010). Two Instructional Models That Teacher Can Use to Promote \& Support Scientific Argumentation in the Biology Classroom. The American Biology Teacher, 72 (7), 427-431

Siswanto, Kaniawati, I. \& Suhandi, A. (2014). " Application of Argument Generating Learning Models Using Scientific Methods to Improve Cognitive Abilities and Student's Argumentation Skills." Indonesian Journal of Physics Education, 10 (2), 104-116.

Sondang, R. (2012). Identification of Argumentation Skills Through Analysis "Toulmin Argumentation Pattern (TAP)" on Topics of Kinematics for Prospective Teachers. Seminar in Mathematics and Natural Sciences, State University of Medan, 11-12 Mei 2012.

Stigler, J. W., Gonzales, P., Kanakawa, T., Knoll, S., \& Serrano, A. (1999). The TIMSS Videotape Classroom Study: Methods and findings from an exploratory research project on eighth-grade mathematics instruction in Germany, Japan, and the United 
States. U.S. Department of Education, National Center for Education Statistics (1999NCES 99-074). Washington, DC.: U.S. Government Printing Office (http://nces.ed.gov/timss).

Widodo, A. (2005). Biological Learning Analysis Using Video. Paper presented at the National Seminar on Science Education III of the Association of Scholars and Observers of Indonesian Science Education, July 22-23, 2005, Bandung.

Widodo, A. \& Ramdhaningsih, V. (2006). Analysis of biology practicum activities using video. Metalogica. 9(2), 146-158.

Zohar, A., \& Nemet, F. (2002). Fostering Students Knowledge and Argumentation Skills through Dilemmas in Human Genetics. Journal of Research in Science Teaching, 39 (1), 35-62 